\title{
Self-employment. The Case of Spain
}

\section{Guillermo Ceballos Santamaría}

$\mathrm{PhD}$ in Economics, University of Castilla-La Mancha, Spain

Juan José Villanueva Álvaro

$\mathrm{PhD}$ in Economics, University of Castilla-La Mancha, Spain

\section{José Mondéjar Jiménez}

$\mathrm{PhD}$ in Economics, University of Castilla-La Mancha, Spain

\begin{abstract}
This article is a study on self-employment in Spain, and particularly on a target group: worker-members of small limited liability companies. Through the descriptive analysis of a sample of workers extracted from the Continuous Work History Sample (CWHS), on the one hand, we evaluate the conditions which determine the decision to become your own employer, and on the other hand, we reflect a number of sociodemographic characteristics related to the working life of our target group. The most relevant result demonstrates that worker-members of small and medium-sized enterprises (SMEs) can be differentiated as an independent group with its own features, despite the economic literature has usually studied them within the selfemployed workers' collective. This group represents about a quarter of the totality of the Spanish selfemployed work, thus becoming a very important part of the national economy in the wealth and employment creation.
\end{abstract}

Keywords: self-employment, worker-members, SMEs.

JEL Classification: J23, J24, L26.

(C) The Authors, 2018. This article is published with open access at Sumy State University.

\section{Introduction}

The economic literature has addressed the decision of becoming a self-employed worker from two different angles: the macroeconomic and the microeconomic approaches. The first one analyses the evolution in the self-employment rates and links them with macroeconomic variables, especially with GDP development, changes in the institutional setting, and fiscal and labour policies. The microeconomic approach studies individual circumstances and decisions in working life, and tests carried out using samples extracted from microeconomical databases, obtained through household surveys.

Traditionally, the self-employment has been associated with the lack of employment opportunities, which would enforce unemployed people to set up their own business, regardless of their entrepreneurship. Times of economic recession would be adjusted to this circumstance owing to the high levels of unemployment. In this line, some authors (González, 2009; Cuadrado y Del Río, 1993; Evans y Leighton, 1989) claim that selfemployment revives in the GDP stagnation periods, since the loss of expectation of finding a job of unemployed people forces them to try the adventure of becoming their own bosses (Álvarez et al., 2013; Ceballos, 2016). However, in the opposite direction, there are also works (Carmona et al., 2012; Blanchflower and Oswald, 1991; Taylor, 1996) which claim that cycles of economic prosperity favour the development of new opportunities and, with them, the creation of self-employment jobs.

The socio-demographic, academic and occupational factors of the individual are also determinants which condition the probability of becoming an entrepreneur. The academic literature has been recurrent in the study of "classical" factors, such as professional skills, family wealth (and their own), gender and work environment. It has been shown that the division of tasks in the home family favours that males become selfemployed workers to a greater extent that women, and that the businesses run by males usually survive for a longer time (Millán et al., 2012). Moreover, the accumulation of human capital, either through academic training or the accumulation of experience in previously performed jobs, do not clearly determine the greater likelihood of becoming a self-employed worker (Van Der Sluis et al., 2008). On the contrary, there are other very favourable factors in which the majority of authors seem to agree, such as the ease for obtaining initial 
financial resources or the availability of business history within the own family (Georgellis et al., 2005; Congregado et al., 2006).

The referenced economic literature evidences that there are few differences between the characteristics of the Spanish self-employment and the self-employed workers from the rest of the developed economies of the world. We analyse in this study a specific group of Spanish self-employed workers, distinguishing within the self-employment between those who are both self-employed people and workers-members of their own SMEs; they are both workers and funding partners (Ceballos y Villanueva, 2014). Qualitative and quantitatively, this is a significant group around which we will make a socio-demographic and occupational analysis. In addition, we will compare this group with the traditional figure of the self-employed worker, i.e., the individual entrepreneur that develops his activity as a legal person.

\section{Materials and methods}

The database used in this study is the Continuous Work History Sample, henceforth CWHS. CWHS is the result of the merger of different sources (Spanish Social Security, Municipal Register of Inhabitants and State Tax Administration Agency). This is a register carried out by the Spanish Ministry of Employment and Social Security since 2010 (the database used in this work is from this year), on the basis of a sample of people related with the Social Security during that year. We have carried out a simple random sampling of the $4 \%$ with a raising factor of 25 on this reference population.

For undertaking the selection of our sample, we start from a total of 17,943,071 records listed in the 2010 CWHS. We have identified the "active" records, which correspond to the people who are enlisted in the Social Security the $31^{\text {st }}$ December 2010. In a first stage, we delete the "inactive" records in this moment; among them, the recipients of retirements pensions and the deceased people during the year. Then, we have extracted the records corresponding to active workers, excluding individuals who, even if they are registered as working, are recipients of unemployment benefits, and people who have a special agreement with the Social Security for the collection of future retirement pensions. Thus, we only analyse the employed people by the end of 2010, with a final outcome of 691,231 records. Finally, for identifying the object of our study (workers-members of SMEs), we combine variables from the affiliation database (affiliation to the Social Security scheme) with other variables from the tax database. Cross-referencing both variables, we select those employees who declare wage incomes from capitalistic companies (limited or public) that, at the same time, pay Social Security contributions through the Special Scheme for Self-Employed Workers (RETA in Spanish). In this way, we identify the employees for tax purposes who are also self-employed workers for labour contribution purposes. As shown in Table 1, there are 29,703 worker-members in the register.

\section{Results}

Once identified the target group of our study in the CWHS, we statistically describe it from its sociodemographic characteristics, and also from the characteristics related to their working lives. In this way, we can reflect the socio-economic reality of the worker-members of SMEs, configuring them as an independent group of the classic self-employed workers (individual entrepreneurs who develop their activity as legal persons) and employees.

We start the descriptive work with the overview of the collectives, according to their socio-demographic characteristics (gender and age). We will try to determine whether there is a pattern that defines them, i.e., if there are personal singularities that are associated with the belonging to one or another group.

In the Table 2, we present the gender distribution. In each one of the groups, the percentage of males is higher than females; however, it is reflected a greater imbalance in the distribution by gender of the workermembers' group: seven out of ten are males. In the introduction, we have pointed out that it is more common to find male entrepreneurs, and that the probability of accessing and sustaining the self-employment is also superior in males. Raising children is more difficult for females when becoming an entrepreneur or facing the initial problems of businesses: variable incomes, and generally, long, irregular working days. The difference in the composition by gender between the two groups of self-employed workers (worker-members facing the classic self-employed workers) is striking: the percentage of males is higher in worker-members although the conditions of access and continuity in self-employment, because of gender, should not differ between males and females of both groups. 
The age distribution in the different collectives (Table 3) reflects that the self-employed workers systematically have older ages than employees.

The higher average age of the self-employed workers against the employees has partly to do with the later date of incorporation to self-employment. The self-employed worker prefers to accumulate experience (normally as an employee) before setting up his company. We also detect that our collective abandons the work in active with a higher age than employees; they retire earlier. In worker-members, the value of the percentile five ( 28 years-old) is five years superior to the employees' one; that is to say, they enter the working life five years later. On the other side, in the percentile ninety-five (62 years-old), we also notice a permanence in the labour market during three years more. When we analysed the distribution of the different groups by age, it is reflected that worker-members are the collective with the largest percentage of workers between 36 and 55 years-old. This circumstance could be due to the fact that, in the first years of their working life, they accumulate the necessary human and financial capital (experience and economic resources) for setting up their business. Once the company is operative, they defend its continuity without considering labour changes towards other collectives.

The observed personal characteristics define the average worker-member as male and experimented; moreover, he joins in his collective when considers that has enough working and economic skills.

With the purpose of analysing the work experience of the target group of our work, we have studied certain characteristics of their working lives. The observation of the accumulated working life by worker-members can help us understand how powerful is the commitment with their companies. In the same way, to find out the unemployment periods during their working lives, and in particular, to know if they have been unemployed before their current job will help to assess if self-employment is a thorough, voluntary decision. On the other hand, it could be the refuge for a labour market which doesn't offer employment opportunities.

The Table 4 reflects the basic characteristics of the distribution of the accumulated potential working life of each target group. This is defined as the time elapsed since the first time that the person enrolled the Social Security until the date of the sample, regardless of the scheme or schemes by which he circulated. Consistently with the distribution by age, we noticed that the components of our group accumulate a longer working life. It is interesting to analyse the percentile 5 of the working life of individuals with a value that surpasses the rest of collectives doubling the employees' one.

Since the CWHS offers the possibility of consulting the working lives, we have clustered them depending on what was their employment situation preceding to their current situation in the date of selection/fixing of the sample (31/12/2010). We have created five groups of workers in each collective: The first group is formed by those individuals that had not previously worked (at least, legally). The second group is formed by those workers who directly come from another job. That is to say, they have changed of job without any period of inactivity between the last job and the active at the end of 2010. The third group includes those whose previous situation was a period of unemployment with benefits. The fourth group includes workers that had previous jobs, but the immediately previous episode to the current one was inactivity or unemployment without benefits. For example, they stopped working without having generated right to benefits and, from that position, they have accessed to their current situation. The last group is formed by workers who had been recipients of finished unemployment benefits; they worked, stopped working, claimed the benefits to which they were entitled, and these finished.

The results obtained (Table 5) reflect that self-employment seems to perform the function of refuge for unemployment (both in the case of classic self-employed workers and in the case of worker-members). In relative terms, the percentage of self-employed workers that come from the unemployment without benefits or have finished these benefits (fourth and fifth analysed group) exceeds the $50 \%$. On the other hand, there is a greater percentage of employees (in comparison with the rest of collectives) that come from an unemployment situation in which they continue receiving benefits. In the light of the results obtained, we can formulate the hypothesis that, while receiving benefits, unemployed people don't consider self-employment as a form of employment; they keep the hope of finding another job as employees. However, when they do not receive any type of benefit, the possibility of considering the self-employment as a job opportunity gains importance. The percentage of worker-members who finished their benefits more than doubles the percentage of people in the same situation who obtained a new employment contract. 
It is interesting to indicate that, while the worker-members and classic self-employed workers maintain a similar trend, the latter reflect greater percentages of workers in this extreme situation. More workers decide to become classic self-employed workers when they no longer earn unemployment benefits. Part of this difference may be conditioned by the fact that, for classic self-employed workers, it is easier to register themselves in an economic activity and resign again if the project is not viable. We must also add that an unemployed person who becomes a classic self-employed worker could become in a "fake self-employed worker": an employee who is obliged by his employer to register in the RETA with the sole purpose of reducing the costs of contribution to Social Security, although he maintains the same status in the company. This labour fraud is more difficult with the worker-members because, in order to be configured as such, they must previously constitute a legal entity (public or limited liability company) with the economic and administrative management cost that this entails. The worker-member faces more entry and exit barriers in the economic activity that develops.

\section{Conclusions}

In the present study, we have identified and described the socio-economic and labour situation of a significant part of the Spanish self-employed workers, with specific characteristics that differentiate them from the rest of "worker-members". This group is formed by people who are partners of SMEs (whose predominant legal form is limited liability company). They have enough social capital to make decisions in their companies and, at the same time, are workers in the company. We have a singular collective with quantitative and qualitative importance within the Spanish labour market.

The results have shown a greater concentration of males in the worker-members collective than in any other of the analysed. On the other hand, women who work outside home mostly choose wage labour, or to collaborate in family businesses. In addition, self-employed women opt for self-employment more as classic selfemployed workers than as workers-members. For their part, the probability of belonging to any of the two groups of self-employed workers studied (worker-members and classic self-employed workers) increases with the age and the accumulation of experience throughout working life.

Regarding the possible role of self-employment as "refuge" in times of economic recession, the existing relationship between the previous stages of job insecurity suffered by individuals who belonged to any of the self-employment collectives is evidenced. However, worker-members seem to have a greater entrepreneurship, since the classic self-employed workers are better adapted to a temporary situation of unemployment, waiting for new labour opportunities. In addition, the figure of the fake self-employed worker, understood as that employee who is obliged to register himself as a self-employed worker to reduce Social Security contributions of his employer, is much more suited to classic self-employed workers than to worker-members.

\section{References}

1. Álvarez, G., Gradín, C., Otero, M. (2013). Self-Employment: Transition and Earnings Differential. Revista de Economia Aplicada, 21(2), 61-90.

2. Blanchflower, D., \& Oswald, A. (1991). Self-employment and Mrs. Thatcher's enterprise culture. CEP working paper, 30 .

3. Carmona, M., Congregado, E., Golpe, A. (2012). Comovement Between Self-Employment and Macroeconomic Variables Evidence From Spain, SAGE open, 1-7.

4. Ceballos, G. (2016). Los socios trabajadores de las pymes españolas (Tesis doctoral). Universidad de Castilla- La Mancha, Cuenca.

5. Ceballos, G., \& Villanueva, J. (2014). Common financial Data and Tax and Accounting Strategies in Spanish Micro-Enterprises. International Business \& Economics Research Journal, 13(7), 1565-1570.

6. Congregado, E., Golpe, A., Millán, J. (2006). Los autónomos en el mercado de trabajo español: situación, políticas y retos. Perspectivas del Sistema Financiero, 86, 1-19.

7. Cuadrado, J. R. \& Del Rio, C. (1993). Los servicios sociales en España. Pirámide, Madrid.

8. Evans, D. \& Leighton, L. (1989). Some empirical aspects of entrepreneurship. American Economic Review, 79(3), 519-535.

9. Georgellis, Y., Sessions, J., Tsitsianis, N. (2005). Self-employment longitudinal dynamics: A review of the literature. Economic Issues, 10(2), 51-84.

10. González, O. (2009). Evolución del empleo autónomo en las regiones españolas y su relación con el crecimiento económico y el empleo. Revista de Estudios Regionales, 84, 203-221. 
11. Millán, J., Congregado, E., Román, C. (2012). Determinants of self-employment survival in Europe. Small Business Economics, 38(2), 231-258.

12. Taylor, M. (1996). Earnings independence or unemployment: Why become self-employed? Oxford Bulletin of Economics and Statistics, 58, 253-266.

13. Van Der Sluis, J., Van Praag, M.,Vijverberg, W. (2008). Education and entrepreneurship selection and performance: A review of the empirical literature. Journal of Economic Surveys, 22(5), 795-841.

\section{Appendices}

Table 1. Identification of the Groups (Number of Records)

\begin{tabular}{|c|c|c|}
\hline & Payer & Group \\
\hline \multirow{2}{*}{$\begin{array}{l}\text { Special scheme for self- } \\
\text { employed workers }\end{array}$} & Payer: public or limited company & $\begin{array}{c}\text { Worker-members } \\
29,703\end{array}$ \\
\hline & Other payers & $\begin{array}{l}\text { Rest of self-employed workers } \\
92,418\end{array}$ \\
\hline General scheme & Any payer & $\begin{array}{c}\text { Employees } \\
569,110\end{array}$ \\
\hline Total & & \\
\hline
\end{tabular}

Source: compiled by authors based on the 2010 CWHS.

Table 2. Gender Distribution. Percentages

\begin{tabular}{|c|c|c|c|}
\hline Gender & Employees & Classic self-employed workers & Worker-members \\
\hline Male & 53.57 & 64.69 & 71.93 \\
\hline Female & 46.43 & 35.31 & 28.07 \\
\hline Total & 100.00 & 100.00 & 100.00 \\
\hline
\end{tabular}

Source: compiled by authors based on the 2010 CWHS.

Table 3. Age of the Active Participants

\begin{tabular}{|c|c|c|c|c|c|}
\hline Age & Average & Standard deviation & Median & Percentile 5\% & Percentile 95\% \\
\hline Employees & 40.01 & 10.98 & 39 & 23 & 59 \\
\hline Classic self-employed workers & 45.68 & 10.92 & 46 & 28 & 63 \\
\hline Worker-members & 44.76 & 10.63 & 44 & 28 & 62 \\
\hline
\end{tabular}

Source: compiled by authors based on the 2010 CWHS.

Table 4. Accumulated Working Life in Years

\begin{tabular}{|c|c|c|c|c|c|}
\hline & Average & Standard deviation & Median & Percentile 5\% & Percentile 95\% \\
\hline Employees & 18.87 & 11.30 & 17.27 & 3.27 & 39.03 \\
\hline Classic self-employed workers & 23.23 & 10.91 & 22.92 & 5.74 & 39.90 \\
\hline Worker-members & 23.61 & 10.49 & 23.06 & 6.90 & 39.90 \\
\hline
\end{tabular}

Source: compiled by authors based on the 2010 CWHS.

Table 5. Previous Employment Situation. Percentages

\begin{tabular}{|l|c|c|c|}
\hline \multicolumn{1}{|c|}{ Situation before the current job } & Employees & $\begin{array}{c}\text { Classic self-employed } \\
\text { workers }\end{array}$ & Worker-members \\
\hline This is their first job & 5.72 & 14.48 & 11.17 \\
\hline Come from another job & 41.40 & 16.26 & 29.80 \\
\hline Come from unemployment with benefits & 11.74 & 10.76 & 7.99 \\
\hline Come from labour interruption without benefits & 36.07 & 44.80 & 38.60 \\
\hline Finished their benefits & 5.06 & 13.69 & 12.44 \\
\hline Total & 100.00 & 100.00 & 100.00 \\
\hline
\end{tabular}

Source: compiled by authors based on the 2010 CWHS. 